Relations industrielles

Industrial Relations

\title{
Techniques of Labour Relations
}

\section{Fourth Industrial Relations Convention of Laval University}

Volume 4, numéro 7, mars 1949

URI : https://id.erudit.org/iderudit/1023510ar

DOI : https://doi.org/10.7202/1023510ar

Aller au sommaire du numéro

Éditeur(s)

Département des relations industrielles de l’Université Laval

ISSN

0034-379X (imprimé)

1703-8138 (numérique)

Découvrir la revue

Citer ce document

(1949). Techniques of Labour Relations: Fourth Industrial Relations Convention of Laval University. Relations industrielles / Industrial Relations, 4(7), 70-70.

https://doi.org/10.7202/1023510ar

Tous droits réservés @ C Département des relations industrielles de l’Université Laval, 1949
Ce document est protégé par la loi sur le droit d'auteur. L’utilisation des services d'Érudit (y compris la reproduction) est assujettie à sa politique d'utilisation que vous pouvez consulter en ligne.

https://apropos.erudit.org/fr/usagers/politique-dutilisation/ 


\section{TECHNIQUES OF LABOUR RELATIONS}

\section{$4^{\text {th }}$ Industrial Relations Canuention of Laval University CHATEAU FRONTENAC, QUEBEC Monday and Tuesday, May 2nd and 3rd, 1949}

\section{Pragramme}

Monday, May 2nd, 1949

Morning

Chairman: Mr. Gérand Trembay, Deputy Minister of Labour of the Province of Quebec and Director of the Department of Industrial Relations, Faculty of Social Sciences, Laval University.

9.00 Registration.

9.30 Speeches of Mgr. Ferdinand Vandry. P.A., V.G., Rector of Laval University, and of $\mathrm{Mr}$. Gémard Tremblay, Director of the Department of Industrial Relations of Laval University.

10.00 Techniques of Labour Relations: Conciliation and Arbitration.

Me Louis-Philippe Pigcon, K.C., lawyer of the Quebec Bar, professor in the Faculty of Law and the Faculty of Social Sciences of Laval University.

\section{Afternoon}

Chairman: Mr. W. Mortimer Baker. Assistant Manager of Manufacturing, Dominion Engineering Works Ltd., Montreal.

2.30 Techniques of Labour Relations: Organizing the employers.

Mr. Louis Bilodeau, Secretary of the "Association patronale des services hospitaliers de Québec" and Secretary of the Hospital Services Parity Committee for the Eastern district of the Province of Québec. Québec.

4.00 Techniques of Labour Relations: Organizing the workers.

Mr. Jean Marchand, M.Soc.Sc., General Secretary of the Canadian and Catholic Confederation of Labour, Québec.

8.15 Specialized Sessions for the employers, workers, personmel directors, parity committee and labour officials at the Faculty of Social Sciences, 2, rue de l'Université, Québec.

\author{
Tuesday, May 3rd, 1949 \\ Morning
}

Chairman: Mr. Albert Thibeault, Manager, Grand'Mère Knitting Ltd., Grand'Mère, President of the "Association Professionnelle des Industriels".

9.00 Techniques of Labour Relations: Negotiation of Collective Agreement - employers' view. point.

Mr. Hector Cimon, I.C., Vice-President of Industrial Relations, Price Bros. Co. Ltd., Québec.

10.30 Techniques of Labour Relations: Negotiation of Collective Agreement - workers' viewfoint.

Mr. Remi Duquette, Organizer, Trades and Labour Congress of Canada, Montréal.

\section{Afternoon}

Chairman: Mr. T. P. Dalton, Director of Personnel, The Shawinigan Water \& Power Co., Montreal. Member of the Montreal Personnel Association.

2.30 Techniques of Labour Relations: The application of the Collective Agreement and Personnel Administration - employers' viewpoint.

Mr. Lawrence A. Lyons, Personnel Manager, The Montreal Cottons Ltd., Valleyfield.

4.00 Techniques of Labour Relations: The application of the Collective Agreement and Shop Stewards - workers' viewpoint.

Mr. Ren'ê Gosselin, Technician, Fédération Nationale du Textile Inc., Granby.

7.00 Closing dinner Château Frontenac,

FORUMS: Each of the outlines will be followed by an open forum under the direction of the speaker and a committee of discussion during which those attending can discuss the ideas which will have been expressed and give the audience the benefit of their personal experience.

REGISTRATION: The registration fee is ten dollars (\$10) and includes the attendance at the conferences and forums and closing banquet as well as the right to a complete report of the Convention. Because of the necessity to limit the number of members it is recommended that reservations be made as soon as possible to the Secretariat, Department of Industrial Relations, Laval University, 2 rue de l'Université, Québec (tel. 2-3951). 